\title{
INNOVATION IN TOURISM: PERCEPTION OF TOURISM PROVIDERS FROM CROATIAAND SERBIA
}

\section{Iva Slivar, Sanja Božić, Anka Batković}

(1) Faculty of Economics and Tourism "Dr. Mijo Mirković, Juraj Dobrila University of Pula (2) Department of Geography, Tourism and Hotel management, Univerity of Novi Sad, Serbia (3) Faculty of Economics and Tourism "Dr. Mijo Mirković, Juraj Dobrila University of Pula

Iva Slivar Faculty of Economics and Tourism "Dr. Mijo Mirković Juraj Dobrila University of Pula islivar@unipu.hr

Article info Paper category: Preliminary paper Received: 16.10.2016. Accepted: 12.12.2016. JEL classification: L83, O3 


\begin{abstract}
Innovations represent a challenge that every company faces during its life cycle no matter what kind of business sector it operates in. In today's world of competition and fastgrowing industries, it is paramount to be innovative, especially in tourism. The main aim of this study was to determine how businesses and their employees in two countries - Croatia and Serbia, are directed toward new innovations, which innovations are most important to them, what are the main barriers to implementation and if there is a difference between innovation implementation in those two countries. For this purpose, the study was conducted in 13 tourism companies in Croatia and 20 in Serbia, in the period July-October 2016. The results indicate that companies in Croatia $(M=3.86)$ are more open to innovations than Serbian tourism companies $(M=3.50)$. Furthermore, the study showed that respondents have similar wishes and motives when implementing newideas or innovations, such as educated workforce, health and well-being of people or improved business management. However, when it comes to key areas for innovation implementation, in Croatia emphasis should be on training and education of the workforce, while in Serbia emphasis should be placed on the introduction of new technologies. In addition, the key limiting factors of innovation implementation that stood out only in Serbia are lack of funds and poor ownership structure. However, there is willingness to implement innovations and readiness to work towards it. Education and a capable workforce are deemed essential to accomplish and implement new innovations in most companies.
\end{abstract}

\title{
Keywords:
}

innovation; tourism; Serbia; Croatia; tourism providers; SMEs in tourism 


\section{INTRODUCTION}

Nowadays, innovations are important factors that can ensure company's continued growth and income, but on the contrary, if a company is not innovative, it risks the possibility to become uncompetitive on the market. In terms of tourism innovations, one should certainly mention several market brands or individual entrepreneurs such as Thomas Cook, or even global enterprises such as South West Airlines, Expedia, TripAdvisor and Booking. Likewise, when it comes to innovative destinations, places like Las Vegas or Dubai should firstly be mentioned.

However, innovations are not limited to the travel system, they may refer to a small family hotel launching its first website, or just a restaurant that will enrich its offer with a new meal - innovation represents an improvement and a desire to develop an enterprise and adapt its offer to the market needs. Sources of innovation in the tourism industry may originate from outside the tourism sector. One such example is information and communication technology (ICT) which is primarily responsible for innovative tourism development (online services such as e-check-in and online reservation systems). Tourism is also the initiator of many innovations, such as those in the financial sector when it comes to credit cards that allow online purchases and reservations (Hall and Williams, 2008).

Companies that are willing to work on their products or launch new ones are certainly far ahead of their competition. Technology changes, so do the needs of the customers and their way of life. In order to survive the company must monitor its market and keep up with the progress of ICT. Therefore, innovation is the key to success in any industry. Innovation does not imply only new products and services, but also refers to the improvements of the production process, thereby competing with better and new industrial plants, employee education, new work conditions, etc. Producing something in a more economical or cheaper way, or of a higher quality, also has a major strategic role.

The purpose of this paper is to emphasize the importance of innovation specifically for the tourism sector. Moreover, the aim was to explore how ready tourism companies are to implement innovations, how managers and employees are directed toward new innovations, which innovations are the most important to them, what are the main barriers to implementation, etc. Furthermore, the aim was to investigate differences between the two countries in terms of innovation implementation. As Croatia and Serbia are countries with different level of economic development, but also on different stage of development of tourism market, differences on innovation implementation are quite expected in those countries. Hence, the authors assumed that there will be differences between the Croatian and Serbian tourism companies regarding the implementation of innovations, especially regarding key areas for implementing innovations and limitation factors. 
Based on this, three main research hypotheses have been drawn:

$\mathrm{H}$ : Croatia is expected to be more open to new innovations than Serbia.

$\mathrm{H}_{2}$ : Services will be recognized as key areas in which companies should make investments in Croatia, while technology will be primary field for innovation in Serbia.

H3: Low financial resources are expected to be a major obstacle in both analysed countries.

This paper consists of five chapters. The literature review provides an outlook on the term of innovation and reviews key research on the topic of innovation in tourism. The second and third chapter deal with the research methodology and results: namely, tourism employees from Croatia and Serbia were interviewed regarding their attitudes towards innovation. Discussion is presented along with results, while the last section points out concluding remarks.

\section{THEORETICAL REVIEW}

\subsection{Innovation}

"Innovation refers to the process of bringing any new, problem solving idea into use. Ideas for reorganizing, cutting costs, putting in new budgetary systems, improving communication or assembling products in teams are also innovations. Innovation is the generation, acceptance and implementation of new ideas, processes, products or services.... Acceptance and implementation are central to this definition; it involves the capacity to change and adapt." (Hall and Williams, 2008: 5). One of the better known definitions of innovation is that of Schumpeter (1934). By innovation he means, the introduction of new products, new production methods, new markets, new suppliers or setting up new organizational structures of any business. Furthermore, Myers and Marquis (1969) considered that the overall innovation is the total process of certain interrelated "subprocesses", and that innovation is not always the concept of implementation of new ideas, the invention of a new device or the development of new markets, but the sum of all activities of these processes. Innovation, according to one theory, is the "deliberate novelty that brings sustainable benefits" (Mađarić, 2016). These benefits may be directly financial, or represent an increase in quality and safety. An innovation is sustainable when, at least in the medium term, achieves the return on investments along with an increased business stability. Therefore, innovations are intentional, they are not caused by an external "force majeure" (i.e. changing market conditions, sudden change in legislation or a social or a natural disaster). Innovations are the result of research and development capabilities of the individual (innovators) or organized groups of experts.

The term innovation refers to something "completely new or a novelty for the neighbourhood (achieved by transferring other people's experiences to a particu- 
lar environment which previously have not been used), such as contributions that enrich and enhance already known solutions. Unlike scientific discoveries, which cannot be appropriated and legally protected, innovation can be legally protected as intellectual property". (Lexicographic Institute Miroslav Krleža, 2016).

Amabile (1996) defines innovation as successful implementation of creative ideas in any organization or company, and believes that creativity of an individual or a group is the starting point of every innovation. According to the same author, innovation is important because of several reasons:

- lifestyle is changing rapidly and therefore the development of innovations should be adapted to it,

- innovations that manage flexibility are part of the creation of agreements regarding operation of enterprises. Innovations thus require originality, flexibility and creativity.

Hall and Williams (2008: 6) distinguish three types of innovation:

- Incremental - does not require adjustment of the market or new technology, but is manifested as improvement or business growth e.g. reducing waste in the hotel kitchen, acquisition of new cars in a rent-a-car company

- Distinctive - typically requires adjustment of demand and eventually of company organization e.g. an improved system of purchasing plane tickets at a discount.

- Breakthrough - involves a new approach to consumers, new technologies or a new organizational structure e.g. self-check-in or e-tickets.

Whether it is about new products or services, or improvement of existing ones, innovation means change, and in relation to that, Prester (2010: 14) lists three main categories of innovation: product innovation, innovation of the production process and managerial innovations. The latter are defined as "the implementation of new management practices, processes and structures that represent a significant deviation from existing practices and norms" (Jung Erceg and Prester, 2007: 82). Malerba (2001) introduces a "Sectoral system of innovation in production" (SSIP) as a system of innovation which includes several new and already established products and systems from several agents who carried out market and non-market research to create, produce and sell certain products. The sectoral system has the knowledge, technology, resources (inputs) and demand that can be existing or potential. The so-called "agents" which form such systems may be organizations or individual businesses and non-profit organizations. The key elements of SSIP are: products, demand, skills, agents, network interaction, institutions and research and development processes.

Furthermore, there are certain factors that affect innovation, and according to Schrade (2012) these include: technological development, legislation, cooperation and standardization, consumer habits, the price structure, protection of intellectual property. 
Figure 1.: Factors influencing the creation of innovation.

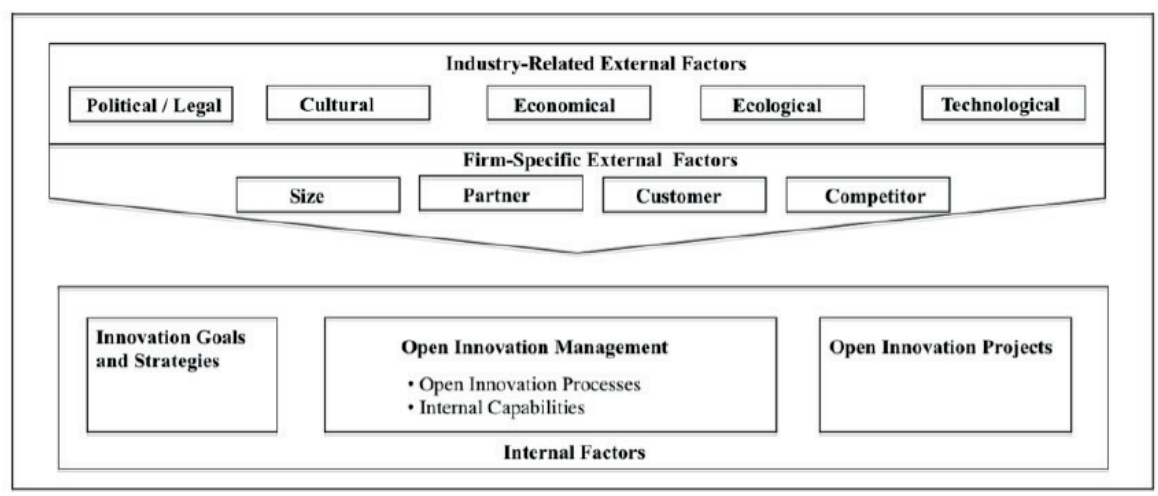

Source: Stucki, A. (2009)

Factors that influence the creation of innovation are, according to Stucki (2009), divided into external factors that affect the industry in which the company operates, external factors closely associated with the operation of the company and internal factors (Figure 1.).

\subsection{Research on innovations in tourism}

Keller (2004) states that innovation in the world of tourism started to develop in the 19th century with the first organized trips by Thomas Cook and later on developed according to the needs and desires of tourists, allowing them to create their own holidays with modular and dynamic packaging and by offering tailor made holidays. In addition, tourism destinations over the years learned to recognize the wishes of tourists and developed some new attractions and offers (Stipanović, Rudan, 2014). Information technology is now driving the development of new innovations in tourism.

Developments in transportation allow passengers to travel faster and easier, which will open up new markets (EU-Lex, 2011). In his multiple case study on ICTdriven and supported innovations in tourism Keller (2004) considers that the right ICTs and freedom of passengers during the organization of their travel are innovations in tourism that are gaining an increasing importance.

Doblin Inc. (2007) presented a comparison of airline companies, accommodation providers and restaurants clients' needs. The survey showed that passengers, when booking their flights, primarily focus on distribution services, while when booking accommodation they value the website, a simple booking process and the perceived quality of service. The restaurant business revealed similar innovation needs as the accommodation one.

By adhering to the element of knowledge, Martinez - Fernandez (2005) presented the KISA concept, "Knowledge intensive service activities", as an important 
part of knowledge and learning in the development of tourism in Australia. His research, which involved 44 tourism companies, showed significant innovations in the implementation of products, new processes and changes in the organization of enterprises, and these innovations are usually incremental. It showed that 39 of 44 companies (89\%), made some changes that involved new products, processes or other related changes, $64 \%$ of them presented a new product, $52 \%$ have implemented a new process, and 50\% have established some other changes, for example, a new way of managing human resources.

The types of innovations in tourism according to Aldabert, B., Dang RJ, and Longhi, C. (2010) are: product and service innovation (most typical), process innovation and innovation in marketing. The research of Martinez - Fernandez (2005) shows that $89 \%$ of Australian companies established innovation in the products or services sector. But innovative approaches in tourism do not necessarily include innovation in services, products and customer experiences, or even operational processes. Innovations are also needed in establishing tourism policies, and therefore Kruger (2004), based on the policy of the Federal Republic of Germany, investigated the importance of innovative approaches in the preparation of tourism policy. He pointed out some specific questions which will be answered with the establishment of a policy which embraces four issues: increasing mobility, the role of new information technologies, population aging and sustainability. In order to achieve such a policy, joint action of the government, organizations, companies and regions is necessary. This innovative tourism policy would have a coherent and synergical effect on the tourism industry.

Regarding the hotel industry and policies hotels should implement in order to be competitive and in line with demand trends, Orfilasintes (2005) discovered that hotels which are part of a hotel chain reported a greater desire for innovation and greater effectiveness in the implementation of innovations in comparison to independent hotels. However, human capital is basic for both individual hotels as well as hotel chains, making investments in human resources a particular innovation or source of innovations. Orfilasintes (2005) also concludes that hotels with higher rating $\left(4^{*}\right.$ and $\left.5^{*}\right)$ are more innovative than other accommodation facilities. Sundby (2007) showed that innovative hotels use more professional management tools, have a positive attitude towards ICT and that their innovative behaviour depends greatly on their size: the larger the company the greater the desire for innovation, which coincides with Orfilasintes (2005) who concludes that among tourism related enterprises, the most innovative are the ones operating in accommodation, transport and F\&B (mainly restaurants). 


\section{METODOLOGY}

The current study on innovation in tourism was conducted with representatives of a certain number of companies engaged in tourism business. Questionnaire (Appendix 1.) was used for collecting data, while the technique used was interview. The survey used for this research was "Unleashing the power of innovation" that has been developed and conducted by "PwC" - Price Waterhouse and Coopers \& Lybrand, and refers to the 19th global questionnaire designed for company directors.

Besides existing questions, authors provided additional ones, in order to adjust the research to the field of innovations in tourism. The interview involved employees of 13 tourism companies operating in the Republic of Croatia, in the region of Istria and Kvarner. The same survey was simultaneously conducted in Serbia on the territory of cities of Novi Sad and Belgrade. On the territory of Serbia employees from 20 different tourism companies were interviewed. Participants were from the sector of accommodation, tourism organisation offices, and travel agencies. The interview consisted of 8 questions related to the innovative ideas of the company, the desire for innovation, openness to new ideas, vision of personal role in the implementation of innovation, future plans related to innovations, personal opinion on best "ingredients" for successful innovation, as well as obstacles to the realization of this goal.

Interviews were conducted by telephone and in direct conversation in the pe$\operatorname{riod} 20 / 07 / 2016-30 / 08 / 2016$ in Croatia and 21/10/2016 - 29/10/2016 in Serbia. It is important to note that the interviews were conducted during the tourist season and many respondents were not able to participate, so only 13 companies in Croatia and 20 in Serbia agreed to participate in the conversation. Moreover, only one company owner in Croatia participated in the study, while five owners in Serbia were interviewed. The rest of the respondents were employees on different positions in tourism companies. Responses were collected via the website www.surveymonkeys.com, in a way that the author entered the answers manually, they were later processed and are shown in the next chapter.

\section{RESULTS AND DISCUSSION}

The principal purpose of the paper was to explore the importance of innovations for tourism sector, as well as to investigate to what extent companies and their employees are focused towards innovations, what kind of innovations are the most important and what are the limiting factors in their realization. Results of the research will be presented simultaneously for Croatia and Serbia, with the main purpose of comparing the results.

The first question concerned employees' opinion on if their company is open to new ideas and innovations. The answers were measured on a 5 -point Likert scale (1Not open at all, 5 -Very open). The results indicate that mean value of this question 
for Croatian companies $(M=3.86)$ is higher than for Serbian companies $(M=3.50)$, which confirms the hypothesis 1 . This finding implies that companies in tourism, both in Croatia and Serbia, are not yet truly open to innovations, but they are willing to make an effort to retain a certain level of creativity. The lower mean value for Serbia may be explained by the fact that Serbia is still not so attractive tourist destination as Croatia, so tourism companies are not so motivated to implement innovations in their business.

In the second question, respondents were asked which of the four statements in the best way describes willingness of their company to implement innovations. The majority of respondents in Croatia $(62 \%)$, as well as in Serbia (55\%) answered „We appreciate innovations and easily recognize new ideas and implement them. The lowest percentage of companies in Croatia (8\%) and Serbia (10\%) stated "Innovations are our priority, we are creative and like new approaches in our business". An equal percent of companies in Croatia (15\%) stated that "Innovations are not our priority because of the market in which we do business" and "Innovations are our priority and we are good in development and implementation of new ideas", while in Serbia $20 \%$ of them stated „Innovations are not our priority because of the market in which we do business", and 15\% said „Innovations are our priority and we are good in development and implementation of new ideas". When comparing the answers, the situation is quite similar in two analysed countries, with the fact that Serbia still has a higher percentage of those who believe that innovations are not their priority because of the market they work with, which may be explained by the fact that travel market in Serbia is less developed than in Croatia, therefore companies in Croatia are more compelled to keep up with the trends and implement innovations.

Furthermore, respondents were asked to describe how they see their role in innovation implementation in their company (Figure 2.). In Croatia, the highest percent $(69 \%)$ of respondents said they see their role as a part of the team, while in Serbia higher percentage of respondents said they see their role as a leader $(4,0 \%)$. The fact that in Serbia a higher percentage of respondents said they see their role in innovation implementation as a leader can be explained by the fact that higher number of company owners in Serbia participated in this research and they are responsible for innovation initiation. 
Figure 2.: Perception of the role of respondents in innovation implementation in their company

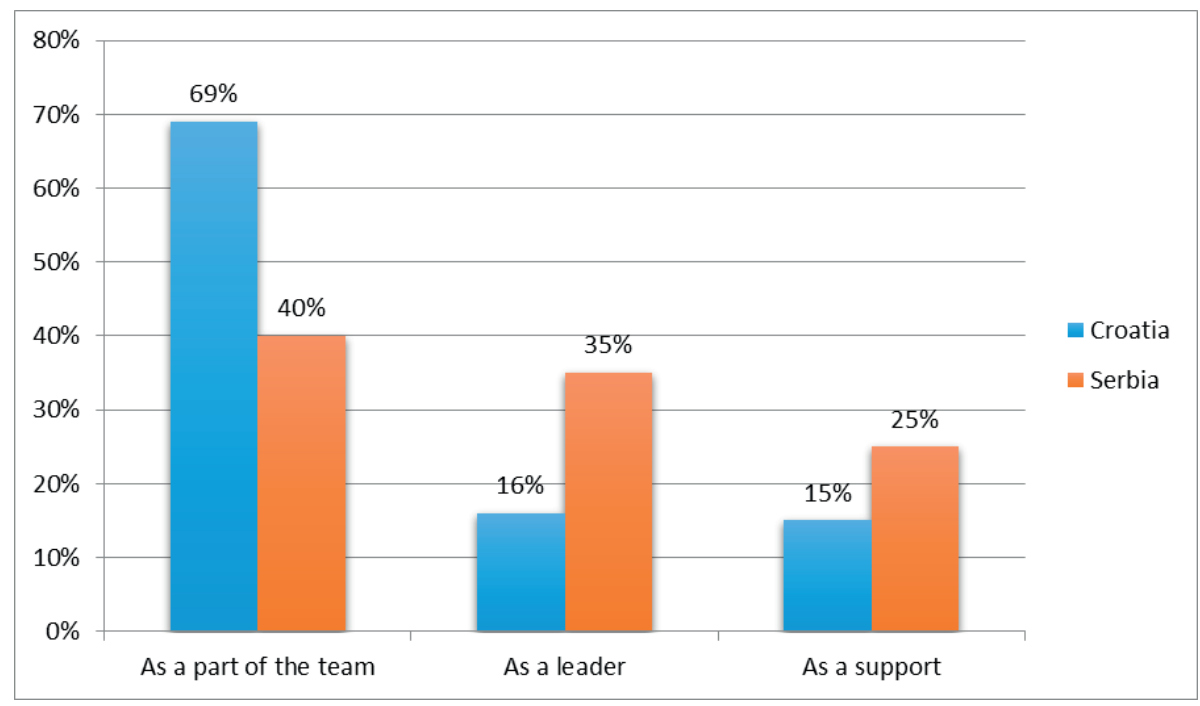

Source: authors'

The respondents were also asked to state which segment of their business they would like to be improved in the next three years. The results are presented in Figure 3., from which we can see that, in both countries, Products, Services and Technology are the top areas that require innovation. This is in line with the studies conducted by Camison (1999) and Monfort (2000), who emphasized the key factors for success and higher competitiveness in tourism development of Mediterranean countries. These factors are as follows: innovation and desire for change, organizational innovations, and modernization of technology, products, services and IT. Monfort (2000) also indicates that willingness of the company to develop and innovate its products, services and technology is necessary if it wants to stay competitive in the market. Serbia, as a less developed country, especially in terms of tourism development, was expected to recognize technology as a top area for innovations, but research has shown that it is almost equally important in both countries. Customer experience has higher priority in Croatia, while Serbian companies believe that changing the business model is important. 
Figure 3.: Business segments that companies would like to improve in the next three years

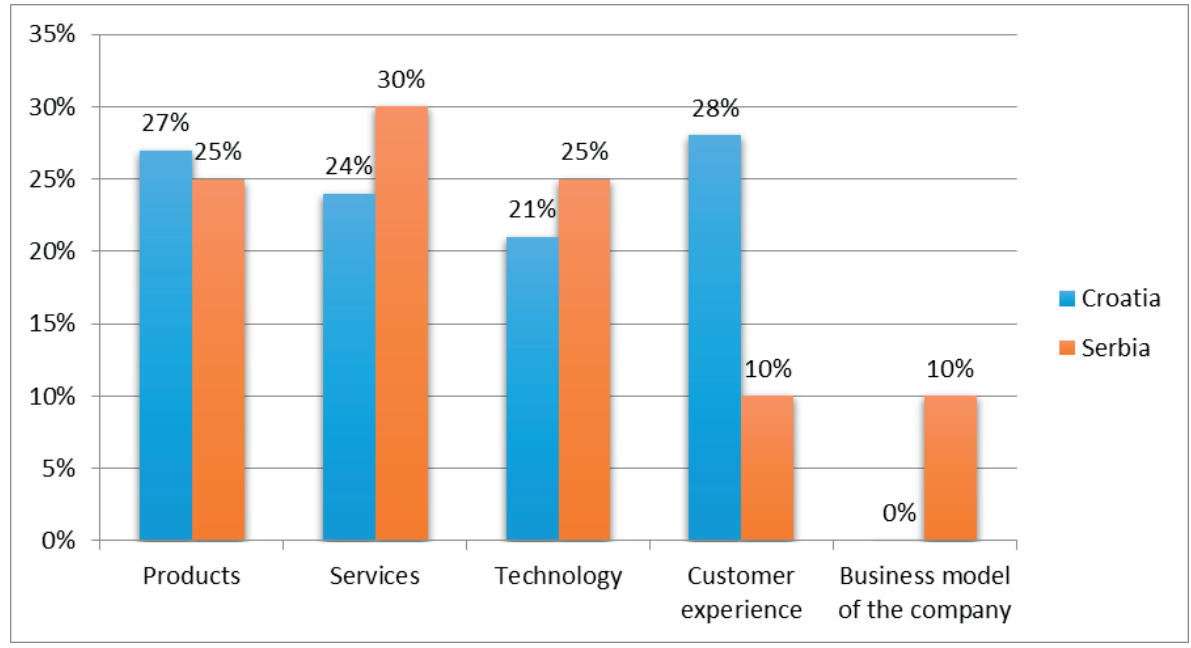

Source: authors'

In the next question, respondents were asked to state the key factor for successful innovations in companies. The results for both countries are presented in Table 1.

Table 1.: The key factors for successful innovations in companies

\begin{tabular}{|c|c|c|}
\hline $\begin{array}{l}\text { Factors for successful } \\
\text { innovations }\end{array}$ & Croatia (\%) & Serbia $(\%)$ \\
\hline Strong vision of a manager & 15 & 15 \\
\hline $\begin{array}{l}\text { Good organisation culture } \\
\text { focused on innovation }\end{array}$ & 12 & 20 \\
\hline $\begin{array}{l}\text { Desire for new challenges and } \\
\text { taking risk }\end{array}$ & 10 & 10 \\
\hline $\begin{array}{l}\text { Good cooperation with } \\
\text { consumers }\end{array}$ & 10 & 5 \\
\hline Creativity & 7 & 15 \\
\hline $\begin{array}{l}\text { Having skills to recognize the } \\
\text { need for new innovations in the } \\
\text { company }\end{array}$ & 20 & 15 \\
\hline $\begin{array}{l}\text { Know how to train and educate } \\
\text { the right people }\end{array}$ & 13 & 5 \\
\hline Use of new technologies & 5 & 10 \\
\hline $\begin{array}{l}\text { Creating a good financial } \\
\text { strategy }\end{array}$ & 8 & 5 \\
\hline
\end{tabular}

Source: authors'

Results indicate that in both countries respondents consider "Strong vision of a manager" and "Having skills to recognize the need for new innovations in the 
company" are among the most important factors for successful innovation. In Serbia, a higher percentage of respondents opted for "Use of new technologies", "Good organisation culture focused on innovation" and "Creativity", while in Croatia they opted more for "Know how to train and educate the right people". In terms of factors which positively affect innovation implementation in the company, it is interesting to mention the research by Nemeth (1997), whose study indicates that those factors are: clear company aims, skilful staff, feedback and adequate award system. From this it can be concluded that preferences and opinions have not significantly changed, as clear aims and educated as well as skilful staff are still of great importance for innovation implementation. A new skill, which is necessary for companies, is certainly the ability to recognize the need for new innovations in the company, as it is important to know when is the right moment for decision making and innovation implementation. The need for innovations has not changed significantly over the years, but there are some new needs that follow modern trends in tourism.

Furthermore, the research aimed to determine obstacles which prevent the company from being innovative. The results for both countries are presented in Table 2.

Table 2.: Key obstacles for successful innovations in companies

\begin{tabular}{|c|c|c|}
\hline $\begin{array}{l}\text { Factors for successful } \\
\text { innovations }\end{array}$ & Croatia (\%) & Serbia (\%) \\
\hline Current organisation culture & $3 \circ$ & 20 \\
\hline Politics and law & $3 \circ$ & 20 \\
\hline Low financial resources & ० & 15 \\
\hline Bad state/private leadership & ० & 15 \\
\hline The lack of employee talent & $3 \circ$ & 10 \\
\hline Out-of-date technology & 10 & 20 \\
\hline $\begin{array}{l}\text { There are no obstacles for our } \\
\text { innovativeness }\end{array}$ & o & ० \\
\hline
\end{tabular}

Source: authors'

From Table 2., it can be concluded that in the case of Croatia, respondents think that Current organisation culture, Politics and law and The lack of employee talent are the major obstacles for innovation, but they also think that Out-of-date technology could be a problem (10\% of respondents). In Serbia, however, factors such as Low financial resources and Bad state/private leadership are considered obstacles, while in Croatia this is not the case. This indicates that hypothesis 3 can be only partially accepted. In addition, more respondents from Serbia think that Out-of-date technology is a problem, while The lack of employee talent is not as big an obstacle as in Croatia. The current study can be connected with the findings of Weiermair (2004), who studied innovation development of tour operators, airlines, hotels, restaurants and theme parks in Northern America and Europe and found that major obstacles for implementing innovations are as follows: lack of time and money, not taking risk, 
lack of skilful employees, modern technology and bureaucracy, conservative opinions and lethargy. By analysing the findings of both studies, it can be observed that bureaucracy, lack of skilled employees and adequate technology, while conservative opinions and lethargy can be connected with organisation culture.

Finally, the respondents were asked which statements should be a priority for the government or companies. In Croatia, the majority of respondents stated that these are „Educated and skilful employees" (68\%), „High employment rate ${ }^{\text {" }}(21 \%)$ as well as "Adequate infrastructure" (11\%). The same priorities were confirmed in Serbia - "Educated and skilful employees" (5०\%), Adequate infrastructure" (25\%), "High employment rate" (15\%) as well as "More equal incomes for citizens" $(10 \%)$.

\section{CONCLUSION}

Tourism innovation process has started moving upwards, particularly with the increasing development of information and communication technologies and the availability of the Internet that greatly assist the development of innovation. Based on this it can be stated that ICT represents the cornerstone of global tourism development. The innovation process in tourism enterprises contributes to their greater competitiveness, and besides new products and services, innovations are also reflected in new ways of conducting business and in the reform of organizational structure.

Innovations are affected by many factors which must be taken into account in innovation planning so that company could successfully respond to their demands. Not every innovation is suitable for every company. In order to enable entrepreneurs to know when, how and in which innovations to invest their finances, time and knowledge, it is necessary to understand the company's business, its advantages and disadvantages. In addition, there are many other conditions, which must be fulfilled in order for successful implementation of innovations, and that companies could efficiently use the results brought by innovations. In this research, conducted among employees of tourism companies in Croatia and Serbia, the main conclusions indicate that employees are willing to work as a team in order to provide their consumers and tourists with unique experiences, by learning and by establishing new ideas and innovation. They believe that the key to success are good leadership of the company and recognizing the need for innovation, as well as trained and educated workforce. When it comes to key areas for innovation implementation, in Croatia, the emphasis should be on training and education of the workforce, while in Serbia, emphasis should be placed on the introduction of new technologies. Furthermore, the lack of funds and poor ownership structure stand out as obstacles to the innovation implementation only in Serbia, and these are the areas that should be improved in the future. In Serbia, unlike Croatia, there is a higher percentage of those who believe that innovations are not a priority because of the tourist market in which they do business, which indicates that companies in Serbia still 
believe that tourist market is not sufficiently developed, and therefore, they do not need to invest in innovations. The authors believe that this view is fallacious, as introducing innovations could make tourist market more competitive and would result in better service, which would in turn attract more tourists.

When comparing this study with relevant research, it can be concluded that there are similarities in the needs for the development of innovation in the tourism industry, since the priority areas are products and service development, technology, professional staff and a clear vision of company managers.

Similar to other related studies on the topic of innovation in tourism, it is evident that the largest number of innovations is related to products and services, in both directions, whether it is about improving existing ones or introducing entirely new ones (most innovations are implemented in larger companies or hotel chains that have a more professional approach to business management). Along with the indispensable ICT, innovations in products and services, as well as in customer experience, in both Croatia and Serbia, stand out as priority areas of innovation, which again is in line with the general hypothesis that products and services are among priority fields for innovation.

Among soft management skills, a new one should be cherished: the ability to recognise the need for innovation. Other managerial implications are related to leadership - having a strong vision and creating an organisational culture that is aimed at creativity, problem solving and empowerment with the adequate support of lifelong learning for both managers and employees.

The possible limitation of this research is a relatively small number of managers who have participated in this exploratory study. The future studies should include more tourism companies and involve in the survey both managers and other employees. The comparison of their opinions could be beneficial for determining the problems of innovation implementation in companies.

Although innovation in tourism is essential, the research on this subject is still in its infancy, considering its complexity as a phenomenon that cannot be reduced to selling products and services; which makes this a call to action for future research. 


\section{Appendix 1. Questionnaire (without demographic questions)}

1. Please rate from 1 (min.) - 5 (max.) how open is your company for new ideas and innovation?
a) 1
b) 2
c) 3
d) 4
e) 5

2. Which of the following statements best describes your company's appetite for innovation?

a) Innovation is not a priority for us in the markets in which we operate.

b) We value innovation. We're good at recognising new ideas and approaches and adopting them quickly

c) Innovation is one of our priorities. We are good at generating new ideas and approaches.

d) Innovation is our primary focus. We are creative and regularly pioneer cutting edge ideas and approaches.

3. Which of the following do you see as your primary role in driving innovation within your organisation?
a) Leader
b) Visionary
c) Layer
d) Sponsor
e) Part of the team
f) Support

4. In which of the following areas is your company looking to innovate over the next 3 years?
a) Products
b) Business model
c) Customer experience
d) Technology 
e) Supply chain and channels to market

f) Services

g) System and processes

h) None / don't know

i) Other

5. What do you think are the most important ingredients for successful innovation at a company?

a) Strong visionary business leadership

b) Having the right culture to foster and support innovation

c) The willingness to challenge organisational norms and take risks

d) Collaborating with customers

e) Having a capacity and capability for creativity

f) The ability to capture ideas throughout the organisation

g) Being able to locate and train the right people

h) Collaborating with suppliers

i) Being able to secure the right levels of funding

j) Use of new tech (such as social media) to support innovation

k) None/Don't know

6. Which of the following constraints is stopping you from being more innovative?
a) Financial resources
b) Existing organisation culture
c) Lack of talent
d) Political and regulatory factors
e) Inadequate technology
f) Nothing is stopping me from being innovative
g) Weak governance/leadership 
7. Which of the following statements should be a priority to government/ company in the country your organisation operates?
a) Adequate infrastructure (physical and digital)
b) Educated and skill workers
c) A high level of employment
d) Reduction of negative impact on environment
e) Equal distribution of basic citizen incomes
f) Health and welfare of the human resources
g) Diversity of employees and their social activism 


\section{REFERENCES}

Aldabert B., Dang R. J., Longhi C., Innovation in the tourism industry: The case of Tourism@ Tourism management, $32(5),(2011): 1204,-1213$

Alkier Radnić R., Turizam u Europskoj uniji, Sveučilište u Rijeci, Fakultet za menadžment u turizmu i ugostiteljstvu, Opatija, 2009

Bartoluci M., Upravljanje razvojem turizma i poduzetništva, Školska knjiga, Zagreb, 2013

Buntak K., Drožđek I., Čovran L., Upravljanje razvojem proizvoda. Tehnički glasnik, 9.1, (2015): 104-111

Camison C., Monfort-Mir V. M., Measuring innovation in tourism from the Schumpeterian and the dynamic-capabilities perspectives, Tourism management, 33.4: 776-789, 2012, accessed September 6, 2016, http://mobiroderic.uv.es/bitstream/handle/10550/44374/087567.pdf? sequence=1\&isAllowed=y

Curić Z., Glamuzina N., Opačić V. T., Geografija turizma, Zagreb, 2013

Doblin Inc., Innovation landscape176, 2007., accessed September 7, 2016, https://www.doblin.com/

Gržinić J., Međunarodni turizam, Sveučilište Jurja Dobrile u Puli, Fakultet ekonomije i turizma „Dr. Mijo Mirković", Pula, 2014

Hall C. M., Williams A. M., Tourism and Innovation, Routledge Taylod \& Francis Group, London and New York, 2014, accessed April 8, 2016, http://mkt.unwto.org/publication/unwto-tourism-highlights-2016-edition

Jung Erceg P., Prester J., Inovacije u proizvodnji - Hrvatsko - Njemačka komparativna analiza, Zbornik Ekonomskog fakulteta u Zagrebu, godina 5, 2007

Keller P., Conclusions of the Conference on Innovation and Growth in Tourism. In: Conference on Innovation and Growth in Tourism, 2004., accessed September 7, 2016, http://www.oecd.org/cfe/ tourism $/ 34,267885 \cdot \mathrm{pdf}$

Krüger H., The need for an innovation-oriented tourism policy, 2004., accessed September 7, 2016, https://search.oecd.org/industry/tourism/34268094.pdf

Kumar P., according to AMABILE, (1996.), Faktori koji utječu na kreativnost i inovacije, 2014.., accessed May 20, 2016, http://www.slideshare.net/princejustleavehimalone/factors-influencing-creativity

Leksikografski zavod Miroslav Krleža, Ideja, accessed May 13, 2016, http://www.enciklopedija.hr/ natuknica.aspx?id=26905

Lex-EU: "WHITE PAPER Roadmap to a Single European Transport Area - Towards a competitive and resource efficient transport system /* COM/2011/0144 final */", accessed November 2, 2015, http://eur-lex. europa.eu/legal-content/EN/TXT/?uri=celex:52011DCo144

Mađarić M., ICT Business, 2016, accessed May 13, 2016, http://www.ictbusiness.info/kolumne/ inovacija-sto-je-to-zapravo

Malerba F., Sectoral Systems of Innovation and Production: Concepts, Analytical Framework and Empirical Evidence, presented at conference „The future of innovation studies", Eindhoven University of Technology, 2001

Markthal, accessed May3o, 2016, https://www.mvrdv.nl/projects/markethall/

Martinez - Fernandez M. C., Soosay C., Krishna V. V., Toner P., Turpin T. et al., Knowledge-intensive Service Activities (KISA) in Innovation of the Tourism Industry in Australia, University of Western Sydney, 2005 
Nagy A., Review of tourism and hospitality innovation research. Annals of Faculty of Economics, 1.2: 364370, 2012, accessed September 7, 2016, http://steconomiceuoradea.ro/anale/volume/2012/n2/o51.pdf

Nemeth C. J., Managing innovation: When less is more. California management review, 40.1: 59-74, 1997, accessed September 6, 2016, http://www.innovationresource.com/wp-content/ uploads/2015/05/5.-When-Less-is-More.pdf

Prester J., Menadžment inovacija, Sinergija, Zagreb, 2010

Price Waterhouse and Coopers \& Lybrand, „Transforming: technology, innovation and talent”, 2016, accessed July 15, 2016, http://read.ca.pwc.com/i/632013-pwc-19th-annual-global-ceo-surveycanadian-insights

Schrade, Čimbenici koji utječu na inovacije, 2012, accessed May 6, 2016, http://www. europeanpaymentscouncil.eu/index.cfm/newsletter/article/?articles_uuid=AoAD $2 \mathrm{BB}_{5}{ }_{5} 5{ }_{5} 6-\mathrm{B}_{7411^{-}}$ DBCoFEoCG $21 \mathrm{BD}_{18} 5$

Stipanović K. and Rudan E., "Development concept and strategy for creative tourism for the Kvarner destination", Tourism and Hospitality Industry 2014, CONGRESS PROCEEDINGS Trends in Tourism and Hospitality Industry, Opatija, (2014): 507-517

Stucki, Faktori koji utječu na stvaranje inovacija, 2009, accessed May 15, 2016, https://infoscience.epfl. ch/record/142841/files/PaperGPREN_astucki.pdf str. 9

UNWTO Tourism highlights, 2015 Edition, accessed April 8, 2016, http://www.eunwto.org/doi/ pdf/10.18111/9789284416899

UNWTO Tourism highlights, 2016 Edition, accessed April 8, 2016, http://www.eunwto.org/doi/ pdf/10.18111/9789284416899

Weiermair K., Product improvement or innovation: What is the key to success in tourism. Innovations in tourism UNWTO conference, 2004, accessed September 6, 2016, https:/www.researchgate.net/profile/ Klaus_Weiermair/publication/24,24,88511_PRODUCT_IMPROVEMENT_OR_INNOVATION_WHAT_IS_ THE_KEY_TO_SUCCESS_IN_TOURISM/links/oa85e53of222e526aeoooooo.pdf 
